\title{
PENDIDIKAN AKHLAK ANAK DALAM KELUARGA MENURUT ISLAM
}

\author{
H. Zulkifli Agus \\ Sekolah Tinggi Ilmu Tarbiyah Raudhatul Ulum Sakatiga \\ Email: zulkifliagus08@gmail.com
}

\begin{abstract}
Abstrak
Secara garis besar pendidikan akhlak anak dalam keluarga dapat dikelompokkan menjadi tiga, pertama pembinaan akidah dan akhlak, kedua, pembinaan intelektual, ketiga, pembinaan kepribadian dan sosial. Dengan demikian pendidikan adalah merupakan hak anak yang menjadi kewajiban atas orangtuanya. Apabila anak kurang dalam pendidikannya, kelak dapat menuntut pertanggungjawaban kepada orangtuanya masig-masing. Untuk mengajarkan pendidikan akhlak kepada anak diperlukan metode dalam penyampaiannya supaya berhasil. Menurut Abdurrahman an-Nahlawi metode pendidikan Islam sangat efektif dalam membina akhlak anak didik, bahkan tidak sekedar itu metode pendidikan Islam memberikan motivasi sehingga memungkinkan umat Islam mampu menerima petunjuk Allah. Metode yang dipakai adalah metode dialog, metode kisah Qurani dan Nabawi, metode perumpaan Qurani dan Nabawi, metode keteladanan, metode aplikasi dan pengamalan, metode ibrah dan nasihat serta metode targhib dan tarhib
\end{abstract}

Kata Kunci: Pendidikan Akhlak, Anak, Keluaga, Islam

\section{Pendidikan Akhlak Anak Dalam Keluarga}

Pendidikan mempunyai peranan penting dalam meningkatkan kualitas sumber daya manusia. Pendidikan merupakan salah satu modal dasar pembangunan suatu bangsa. Setiap manusia dalam perjalanan hidupnya selalu membutuhkan orang lain. Untuk dapat melangsungkan hidupnya manusia senantiasa berusaha untuk mengembangkan akal dan segala kemampuannya. Manusia dalam menghadapi problema kehidupan tidak pernah statis, sejak lahir sampai meninggal selalu mengalami perubahan. Pada perkembangan zaman sekarang ini, pendidikan dapat diartikan sebagai sebuah proses dengan metode-metode tertentu sehingga orang memperoleh pengetahuan, pemahaman dan cara bertingkah laku yang sesuai dengan kebutuhan. (Muhaimin, 1993:173)

Keluarga dalam bahasa Arab adalah al-usroh yang berasal dari kata al-asru yang secara etimologis mempunyai arti ikatan. Kata keluarga dapat diambil kefahaman sebagai unit sosial terkecil dalam masyarakat, atau suatu organisasi bio-psiko-sosiospiritual dimana anggota keluarga terkait dalam suatu ikatan khusus untuk hidup bersama dalam ikatan perkawinan dan bukan ikatan yang sifatnya statis dan membelenggu dengan saling menjaga keharmonisan hubungan satu dengan yang lain atau hubungan silaturrahim (William J Goode, 1995:33). Sementara itu. Al-Razi 


\section{Pendidikan Akhlak Anak dalam Keluarga Menurut Islam H. Zulkifli Agus}

mengatakan al-asru maknanya mengikat dengan tali, kemudian meluas menjadi segala sesuatu yang diikat baik dengan tali atau yang lain. Dalam norma ajaran sosial, asal-usul keluarga terbentuk dari perkawinan laki-laki dan perempuan dan kelahiran manusia seperti yang ditegaskan Allah dalm surat an-Nisa ayat 1 :

Artinya :

Hai sekalian manusia, bertakwalah kepada Tuhan-mu yang Telah menciptakan kamu dari seorang diri, dan dari padanya Allah menciptakan isterinya; dan dari pada keduanya Allah memperkembang biakkan laki-laki dan perempuan yang banyak. dan bertakwalah kepada Allah yang dengan (mempergunakan) nama-Nya kamu saling meminta satu sama lain, dan (peliharalah) hubungan silaturrahim. Sesungguhnya Allah selalu menjaga dan mengawasi kamu.

Di dalam pendidikan akhlak anak dalam keluarga yang terdapat pada buku The National Studi on Family Strength, Nick dan De Frain mengemukakan beberapa hal tentang pegangan menuju hubungan keluarga yang sehat dan bahagia, yaitu:

1. Terciptanya kehidupan beragama dalam keluarga

2. Tersedianya waktu untuk bersama keluarga

3. Interaksi segitiga antara ayah, ibu dan anak

4. Saling menghargai dalam interaksi ayah, ibu dan anak

5. Keluarga menjadi prioritas utama dalam setiap situasi dan kondisi (Jalaludin Rahmat, 1994:107).

Penanaman akhlak sejak dini telah dijelaskan dalam al-Qur'an surat al-Baqarah ayat 132

Artinya :

Dan Ibrahim telah mewasiatkan ucapan itu kepada anak-anaknya, demikian pula Ya'qub. (Ibrahim berkata): "Hai anak-anakku! Sesungguhnya Allah Telah memilih agama Ini bagimu, Maka janganlah kamu mati kecuali dalam memeluk agama Islam.

Secara garis besar pendidikan akhlak anak dalam keluarga dapat dikelompokkan menjadi tiga, yaitu: (Djuju Sujana, 1996:25)

\section{Pembinaan Akidah dan Akhlak}

Mengingat keluarga dalam hal ini lebih dominan adalah seorang anak dengan dasar-dasar keimanan, ke-Islaman, sejak mulai mengerti dan dapat memahami sesuatu, maka al-Ghazali memberikan beberapa metode dalam rangka menanamkan aqidah dan keimanan dengan cara memberikan hafalan. Sebab kita tahu bahwa proses pemahaman diawali dengan hafalan terlebih dahulu (al-Fahmu Ba'd al-Hifdzi).

Ketika mau menghafalkan dan kemudian memahaminya, akan tumbuh dalam dirinya sebuah keyakinan dan pada akhirnya membenarkan apa yang diayakini. Inilah proses yang dialami anak pada umumnya.

Muhammad Nur Hafidz merumuskan empat pola dasar dalam bukunya. Pertama, senantiasa membacakan kalimat Tauhid pada anaknya. Kedua, menanamkan kecintaan kepada Allah dan Rasulnya. Ketiga, mengajarkan al-Qur'an 
Volume 2 Nomor 1 Edisi Juni 2017

P-ISSN : 2541-3686

dan keempat menanamkan nilai-nilai pengorbanan dan perjuangan. Akhlak adalah implementasi dari iman dalam segala bentuk perilaku, pendidikan dan pembinaan akhlak anak. Keluarga dilaksanakan dengan contoh dan teladan dari orang tua. Perilaku sopan santun orang tua dalam pergaulan dan hubungan antara ibu, bapak dan masyarakat.

\section{Pembinaan Intelektual}

Pembinaan intelektual dalam keluarga memegang peranan penting dalam upaya meningkatkan kualitas manusia, baik intelektual, spiritual maupun sosial. Karena manusia yang berkualitasakan mendapat derajat yang tinggi di sisi Allah sebagaimana firman-Nya dalam surat al-Mujadalah : (Zakiah Daradjat, 2011:7)

Artinya:

Hai orang-orang beriman apabila kamu dikatakan kepadamu: "Berlapanglapanglah dalam majlis", Maka lapangkanlah niscaya Allah akan memberi kelapangan untukmu. dan apabila dikatakan: "Berdirilah kamu", Maka berdirilah, niscaya Allah akan meninggikan orang-orang yang beriman di antaramu dan orang-orang yang diberi ilmu pengetahuan beberapa derajat. dan Allah Maha mengetahui apa yang kamu kerjakan. (Depag RI, 434)

\section{Pembinaan Kepribadian dan Sosial}

Pembentukan kepribadian terjadi melalui proses yang panjang. Proses pembentukan kepribadian ini akan menjadi lebih baik apabila dilakukan mulai pembentukan produksi serta reproduksi nalar tabiat jiwa dan pengaruh yang melatar belakanginya. Mengingat hal ini sangat berkaitan dengan pengetahuan yang bersifat menjaga emosional diri dan jiwa seseorang.

Dalam hal yang baik ini adanya kewajiban orang tua untuk menanamkan pentingnya memberi support kepribadian yang baik bagi anak didik yang relativ masih muda dan belum mengenal pentingnya arti kehidupan berbuat baik, hal ini cocok dilakukan pada anak sejak dini agar terbiasa berprilaku sopan santun dalam bersosial dengan sesamanya. Untuk memulainya, orang tua bisa dengan mengajarkan agar dapat berbakti kepada orang tua agar kelak si anak dapat menghormati orang yang lebih tua darinya.

Pada dasarnya keluarga merupakan pilar pertama bagi pendidikan anak. Pembentukan kepribadian seorang anak bersumber dari keluarga. Oleh karena itu, hak-hak seorang anak dalam keluarga dibagi menjadi dua bagian: Hak-hak sebelum kelahiran dan hak-hak setelah kelahiran. Berdasarkan hal ini, dalam pandangan Islam, kewajiban ayah dan ibu dimulai sejak anak belum lahir. Jika kewajibankewajiban tersebut tidak ditunaikan oleh kedua orang tua, hal ini akan berdampak negatif bagi pendidikan dan perkembangan kejiawaan anak. (Muhammad Reysyahri, 2009:19) 


\section{Pendidikan Akhlak Anak dalam Keluarga Menurut Islam H. Zulkifli Agus}

Sementara itu, segala sesuatu yang terjadi di dalam keluarga juga akan berguna bagi anak dalam memahami sebuah makna kehidupan, karena kehidupan pertama anak adalah dalam sebuah keluarga. Oleh karena itu pengalaman-pengalaman yang diterima anak merupakan pendidikan pertama dan paling utama dalam mengenal dan memahami sesuatu. Apabila pengalaman yang didapat selama ia tumbuh dalam keluarga itu buruk akan berpengaruh bagi perkembangan selanjutnya. Karena itu hendaklah segala perilaku orang tua dalam keluarga dapat mengandung makna edukatif bagi anak-anaknya, sebab hal ini akan dijadikan patokan pengalaman yang bermanfaat bagi anak dimasa yang akan datang.

Frued dan Adken mengatakan bahwa pengalaman pada masa kanak-kanak yang menyulitkan walaupun sudah jauh terpendam akan dapat mengganggu keseimbangan jiwa dalam perkembangan selanjutnya. (Suwamo, 1985: 87). Oleh karena itu pengalaman yang dialami anak pada masa kecil hendaklah berupa pengalaman yang mengarah pada suatu pembentukan watak.

Selain peran keluarga tersebut di atas, keluarga juga memegang peranan yang penting dalam bidang pendidikan sebelum mendapatkan pendidikan di luar rumah. Pendidikan dalam keluarga secukupnya masih sangat sempit, meliputi perilaku anggota keluarga, hubungan orangtua dengan anak maupun hubungan orang tua dengan orang lain di luar lingkungan dan lain-lain, dimana segala sesuatunya akan berpengaruh dalam jiwa anak. Sehingga orangtua tidak hanya dituntut sebagai pendidik saja, melainkan juga harus bisa menjadi teman dan suri teladan bagi anakanaknya. Oleh karena itulah keluarga dalam hal pendidikan merupakan sumber pendidikan utama, sebab segala kecerdasan intelektual manusia pertama-tama diperoleh dari orangtua dan para anggota keluarganya sendiri. (Singgih Gunarsa, 1984:9)

Islam sebagai agama yang mengatur tentang segala sesuatu menyangkut kehidupan di dunia, dalam hal ini juga memerintahkan kepada orang-orang yang beriman untuk mendidik dirinya dan keluarga agar tidak terkena siksa api neraka. Perintah ini ditegaskan Allah SWT dalam Al Qur'an Surat At-Tahrim ayat 6 yang Artinya :

Hai orang-orang yang beriman, peliharalah dirimu dan keluargamu dari api neraka yang bahan bakarnya adalah manusia dan batu; penjaganya malaikat-malaikat yang kasar, keras, dan tidak mendurhakai Allah terhadap apa yang diperintahkan-Nya kepada mereka dan selalu mengerjakan apa yang diperintahkan. (Depag RI:448)

Dari ayat tersebut dapat diambil pengertian, bahwa kedua orangtua itu diberi kewajiban untuk mendidik dirinya sendiri dan anggota keluarganya termasuk anakanaknya supaya tidak terjerumus ke dalam siksaan api neraka. Abu Tauhid MS. dengan mengambil pendapat Sayyid Sobiq mengatakan bahwa pengertian menjaga diri dan keluarga dari siksaan api neraka adalah dengan pendidikan dan pengajaran yang berfungsi sebagai sarana atau alat untuk menyelamatkan manusia dari siksa api neraka. (Abu Tauhi, 1990:2) 
P-ISSN : 2541-3686

Dengan demikian pendidikan adalah merupakan hak anak yang menjadi kewajiban atas orangtuanya. Apabila anak kurang dalam pendidikannya, kelak dapat menuntut pertanggungjawaban kepada orangtuanya masig-masing. Dalam upaya melaksanakan pendidikan anak-anaknya dalam keluarga, seharusnya orangtua mengetahui cara mendidik anak di mana mayoritas pemahaman mereka relatif sedikit. Selain itu orangtua juga harus mengetahui tentang keadaan anak yang sedang tumbuh dan berkembang baik fisik maupun psikisnya, sehingga akan memudahkan bagi dirinya untuk melaksanakan tugas mendidik anak-anaknya pada masa kini. Karena kesalahan orangtua dalam memahami keadaan anak akan berakibat kurang baik bagi pendidikan anaknya, yang biasanya kesalahan tersebut baru akan terasa setelah anak menginjak usia remaja.

Apabila pribadi anak yang bertentangan dengan norma-norma yang berlaku di masyarakat, seperti minum-minuman keras, mencuri dan berkelahi, bahkan sampai membunuh sesama teman dan lain-lainnya, kebanyakan disebabkan oleh adanya kesalahan orangtua dalam mendidik dan membina anak-anaknya di dalam keluarga. Biasanya anak-anak yang berbuat semacam itu berawal dari kurang adanya kasih sayang, pengertian dan perhatian dari keluarganya. Oleh karena itu ketenangan dan ketentraman situasi dalam keluarga harus senantiasa diciptakan guna membantu perkembangan anak. Apabila situasi tersebut sudah tercipta, maka pembinaan dan pengarahan orangtua akan mudah diterima anak-anaknya. Sebaliknya, bila anak tidak memperoleh ketenangan dan ketentraman akan mengakibatkan kejiwaan anak sulit untuk diarahkan pada hal-hal yang positif, baik pengarahan yang diterima dari orangtuanya sendiri maupun orang lain.

Anak yang hidup dalam suasana keluarga seperti itu tidak akan mendapatkan suatu keharmonisan hubungan antara orangtua dan anak. Hal ini terjadi karena adanya anggapan orangtua yang salah, bahwa tugas mendidik anak itu cukup dialihkan kepada orang lain seperti pembantu rumah tangga atau lembaga yang lain. Dengan alasan banyaknya kesibukan di luar rumah yang menjadikan dirinya jarang bertemu dengan anak-anaknya, mengakibatkan anak merasa kurang mendapat perhatian dan kasih sayang dari orangtuanya walaupun segala kebutuhan materialnya terpenuhi. Anak yang mendapat perlakuan semacam itu akan terganggu perkembangan kesehatan mentalnya yaitu emosinya mudah terguncang oleh adanya berbagai pengaruh negatif yang datang dari luar, baik yang berasal dari luar negeri maupun dalam negeri. (Zakiah Darajat, 1995:100)

Supaya keadaan dalam keluarga mencapai ketenangan dan ketentraman yang dapat membantu perkembangan anak, maka kewajiban yang harus dilakukan oleh orangtua terhadap anak-anaknya adalah sebagai berikut :

1. Adanya cinta kasih dan disiplin

2. Mengajarkan dan pengalaman agama

3. Membiasakan dan menjaga kesehatan

4. Berbuat baik sesama manusia dan saling menolong

5. Memberikan keteladanan yang baik (Aisyah Dahlan, 1969:21-22) 


\section{Pendidikan Akhlak Anak dalam Keluarga Menurut Islam H. Zulkifli Agus}

Pendidikan yang sudah tertanam dalam diri anak sejak dini dengan baik akan membantu orangtua dalam rangka menciptakan suatu keluarga yang sakinah dan diridhoi Allah SWT. Apabila dalam mendidik anak dalam keluarga tidak benar, maka dapat menurunkan martabat atau nama baik kedua orangtuanya. Kenyataan seperti ini sudah banyak terjadi, apalagi dengan adanya kemajuan sains dan teknologi yang pesat menjadikan dunia ini seolah-olah sempit karena adanya informasi yang canggih, sehingga apa yang terjadi di dunia lain dapat dengan cepat diterima oleh anak-anak baik melalui media masa ataupun media elektronika.

Allah SWT pun menyuruh kita, orang tua, punya rasa khawatir terhadap anakanak kita, sesuai yang termaktub dalam Al Qur'an Surat An Nisa ayat 9:

Artinya :

Dan hendaklah takut kepada Allah orang-orang yang seandainya meninggalkan dibelakang mereka anak-anak yang lemah, yang mereka khawatir terhadap (kesejahteraan) mereka. oleh sebab itu hendaklah mereka bertakwa kepada Allah dan hendaklah mereka mengucapkan perkataan yang benar. (Depag RI:62)

Di ayat itu juga Allah SWT, memberi resep kepada kita agar tidak meninggalkan anak-anak yang lemah. Resepnya adalah tingkatkan kapasitas moral kita dengan bertakwa kepada Allah, menambah kapasitas konsepsional kita sehingga kita mampu berkata yang benar dan perbaiki kualitas amal kita. Pentingnya pendidikan Islam bagi tiap-tiap orang tua terhadap anak-anaknya didasarkan pada sabda Rasulullah SAW yang menyatakan bahwa setiap anak dilahirkan dalam keadaan fitrah.

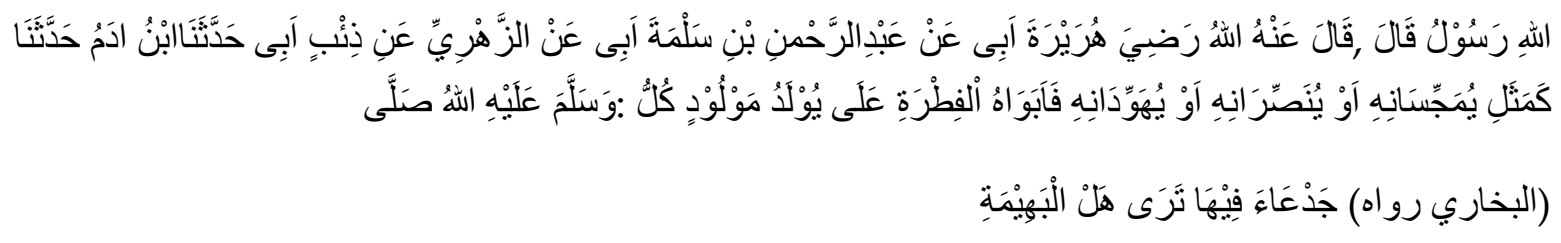

Telah menceritakan kepada Adam telah menceritakan kepada kami Ibn Abu Dza'bin dan Az-Zuhriyyi, dari Abu Salamah bin Abd Rahman dari Abu Huroiroh ra. berkata: Telah bersabdah Rasulullah SAW: Setiap anak dilahirkan dalam keadaan fitrah, maka kedua orangtuanyalah yang menjadikan ia Yahudi, Nasrani, atau Majusi, sebagaimana binatang ternak yang melahirkan binatang ternak dengan sempurna, apakah kalian melihat ada cacat padanya. (HR. Bukhari)

(Imam Bukhari, 1981:182)

Hal tersebut juga didukung oleh teori psikologi perkembangan yang berpendapat bahwa masing-masing anak dilahirkan dalam keadaan seperti kertas putih. Teori ini dikenal dengan teori "tabularasa", yang mana teori ini berpendapat bahwa setiap anak dilahirkan dalam keadaan bersih. ia akan menerima pengaruh dari luar lewat indera yang dimilikinya. Pengaruh yang dimaksudkan tersebut berhubungan dengan proses perkembangan intelektual, perhatian, konsentrasi, 
Volume 2 Nomor 1 Edisi Juni 2017

P-ISSN : 2541-3686

kewaspadaan, pertumbuhan aspek kognitif, dan juga perkembangan sosial. Akan tetapi, perkembangan aspek-aspek tersebut sangat dipengaruhi oleh lingkungan sang anak tersebut. ( Kampus Islam.Com, Peran Pendidikan Islam Dalam Pembentukan Kepribadian Anak di Lingkungan Keluarga, http://www. Kampusislam.com/index.php?pilih =news\&mod=yes\&aksi. Diakses pada 01 maret 2017)

Jadi, karena faktor lingkungan atau faktor luar sangat berpengaruh terhadap perkembangan aspek-aspek psikologis anak, maka peran pendidikan sangatlah penting dalam proses pembentukan dari tingkah laku atau kepribadian tersebut. Dalam hal ini, pendidikan keluarga merupakan salah satu aspek penting, karena awal pembentukan dan perkembangan dari tingkah laku atau kepribadian atau jiwa seorang anak adalah melaui proses pendidikan dilingkungan keluarga. Dilingkungan inilah pertama kalinya terbentuknya tingkah laku atau kepribadian seorang anak tersebut.

\section{Metode Pendidikan Akhlak Anak Dalam Keluarga}

Abdurrahman an-Nahlawi mengatakan metode pendidikan Islam sangat efektif dalam membina akhlak anak didik, bahkan tidak sekedar itu metode pendidikan Islam memberikan motivasi sehingga memungkinkan umat Islam mampu menerima petunjuk Allah. Menurut Abdurrahman an-Nahlawi metode pendidikan Islam adalah metode dialog, metode kisah Qurani dan Nabawi, metode perumpaan Qurani dan Nabawi, metode keteladanan, metode aplikasi dan pengamalan, metode ibrah dan nasihat serta metode targhib dan tarhib. (Abdurrahman an-Nahlawi, 1995:204)

Dari kutipan tersebut tergambar bahwa Islam mempunyai metode tepat untuk membentuk anak didik berakhlak mulia sesuai dengan ajaran Islam. dengan metode tersebut memungkinkan umat Islam/masyarakat Islam mengaplikasikannya dalam dunia pendidikan. Dengan demikian diharapkan akan mampu memberi kontribusi besar terhadap perbaikan akhlak anak didik, untuk memperjelas metode-metode tersebut akan di bahas sebagai berikut:

\section{Metode Dialog Qurani dan Nabawi}

Metode dialog adalah metode menggunakan tanya jawab, apakah pembiacaaan antara dua orang atau lebih, dalam pembicaraan tersebut mempunyai tujuan dan topik pembicaraan tertentu. Metode dialog berusaha menghubungakn pemikiran seseorang dengan orang lain, serta mempunyai manfaat bagi pelaku dan pendengarnya. (Abdurrahman an-Nahlawi, 1995:205) Uraian tersebut memberi makna bahwa dialog dilakukan oleh seseorang dengan orang lain, baik mendengar langsung atau melalui bacaan.

Abdurrrahman an-Nahlawi mengatakan pembaca dialog akan mendapat keuntungan berdasarkan karakteristik dialog, yaitu topic dialog disajikan dengan pola dinamis sehingga materi tidak membosankan, pembaca tertuntun untuk 


\section{Pendidikan Akhlak Anak dalam Keluarga Menurut Islam H. Zulkifli Agus}

mengikuti dialog hingga selesai, melalui dialog perasaan dan emosi pembaca akan terbangkitkan, topic pembicaraan disajikan bersifat realistik dan manusiawi. Dalam al-Quran banyak memberi informasi tentang dialog, di antara bentuk-bentuk dialog tersebut adalah dialog khitabi, taabbudi, deskritif, naratif, argumentative serta dialog Nabawiyah. (Abdurrahman An Nahlawi, 1995:206-238)

Metode dialog sering dilakukan oleh Nabi Muhammad Saw dalam mendidik akhlak para sahabat. Dialog akan memberi kesempatan kepada anak didik untuk bertanya tentang sesuatu yang tidak mereka pahami.

\section{Metode kisah Qurani dan Nabawi}

Dalam al-Quran banyak ditemui kisah menceritakan kejadian masa lalu, kisah mempunyai daya tarik tersendiri yang tujuannnya mendidik akhlak, kisah-kisah para Nabi dan Rasul sebagai pelajaran berharga. Termasuk kisah umat yang inkar kepada Allah beserta akibatnya, kisah tentang orang taat dan balasan yang diterimanya. Seperti cerita Habil dan Qobil :

Ceritakanlah kepada mereka kisah kedua putera Adam (Habil dan Qabil) menurut yang Sebenarnya, ketika keduanya mempersembahkan korban, Maka diterima dari salah seorang dari mereka berdua (Habil) dan tidak diterima dari yang lain (Qabil). ia Berkata (Qabil): "Aku pasti membunuhmu!". Berkata Habil: "Sesungguhnya Allah Hanya menerima (korban) dari orang-orang yang bertakwa. Sungguh kalau kamu menggerakkan tanganmu kepadaku untuk membunuhku, Aku sekali-kali tidak akan menggerakkan tanganku kepadamu untuk membunuhmu. Sesungguhnya Aku takut kepada Allah, Tuhan seru sekalian alam. Sesungguhnya Aku ingin agar kamu kembali dengan (membawa) dosa (membunuh)ku dan dosamu sendiri, Maka kamu akan menjadi penghuni neraka, dan yang demikian Itulah pembalasan bagi orang-orang yang zalim. Maka hawa nafsu Qabil menjadikannya menganggap mudah membunuh saudaranya, sebab itu dibunuhnyalah, Maka jadilah ia seorang di antara orang-orang yang merugi.

Ayat di atas merupakan contoh dalam ayat al-Quran yang berhubungan

dengan kisah. Kisah dalam al-Quran mengandung banyak pelajaran. Kisah dalam alQuran dapat menjadi pelajaran bagi manusia. Abdurrahman an-Nahlawi mengatakan kisah mengandung aspek pendidikan yaitu dapat mengaktifkan dan membangkitkan kesadaran pembacanya, membina perasaan ketuhanan dengan cara mempengaruhi emosi, mengarahkan emosi, mengikutsertakan psikis yang membawa pembaca larut dalam setting emosional cerita, topic cerita memuaskan pikiran. Selain itu kisah dalam al-Quran bertujuan mengkokohkan wahyu dan risalah para Nabi, kisah dalam al-Quran memberi informasi terhadap agama yang dibawa para Nabi berasal dari Allah, kisah dalam al-Quran mampu menghibur umat Islam yang sedang sedih atau tertimpa musibah. 
P-ISSN : 2541-3686

Metode mendidik akhlak melalui kisah akan memberi kesempatan bagi anak untuk berfikir, merasakan, merenungi kisah tersebut, sehingga seolah ia ikut berperan dalam kisahtersebut. Adanya keterkaitan emosi anak terhadap kisah akan memberi peluang bagi anak untuk meniru tokoh-tokoh berakhlak baik, dan berusaha meninggalkan perilaku tokoh-tokoh berakhlak buruk.

Cerita mengusung dua unsur negatif dan unsur positif, adanya dua unsure tersebut akan memberi warna dalam diri anak jika tidak ada filter dari para orang tua dan pendidik. Metode mendidik akhlak melalui cerita/ kisah berperan dalam pembentukan akhlak, moral dan akal anak. (Abdurrahman An Nahlawi, 1995:289296) Dari kutipan tersebut dapat diambil pemahaman bahwa cerita/kisah dapat menjadi metode yang baik dalam rangka membentuk akhlak dan kepribadian anak.

Cerita mempunyai kekuatan dan daya tarik tersendiri dalam menarik simpati anak, perasaannya aktif, hal ini memberi gambaran bahwa cerita disenangi orang, cerita dalam al-Quran bukan hanya sekedar memberi hiburan, tetapi untuk direnungi, karena cerita dalam al-Quran memberi pengajaran kepada manusia. Dapat dipahami bahwa cerita dapat melunakkan hati dan jiwa anak didik, cerita tidak hanya sekedar menghibur tetapi dapat juga menjadi nasehat, memberi pengaruh terhadap akhlak dan perilaku anak, dan terakhir kisah/ cerita merupakan sarana ampuh dalam pendidikan, terutama dalam pembentukan akhlak anak.

\section{Metode Mauizah}

Dalam tafsir al-Manar sebagai dikutip oleh Abdurrahman An-Nahlawi dinyatakan bahwa nasihat mempunyai beberapa bentuk dan konsep penting yaitu, pemberian nasehat berupa penjelasan mengenai kebenaran dan kepentingan sesuatu dengan tujuan orang diberi nasehat akan menjauhi maksiat, pemberi nasehat hendaknya menguraikan nasehat yang dapat menggugah perasaan afeksi dan emosi, seperti peringatan melalui kematian peringatan melalui sakit peringatan melalui hari perhitungan amal. Kemudian dampak yang diharapkan dari metode mauizah adalah untuk membangkitkan perasaan ketuhanan dalam jiwa anak didik, membangkitkan keteguhan untuk senantiasa berpegang kepada pemikiran ketuhanan, perpegang kepada jamaah beriman, terpenting adalah terciptanya pribadi bersih dan suci.

Dalam al-Quran menganjurkan kepada manusia untuk mendidik dengan hikmah dan pelajaran yang baik.

Serulah (manusia) kepada jalan Tuhan-mu dengan hikmah dan pelajaran yang baik dan bantahlah mereka dengan cara yang baik. Sesungguhnya Tuhanmu Dialah yang lebih mengetahui tentang siapa yang tersesat dari jalan-Nya dan dialah yang lebih mengetahui orang-orang yang mendapat petunjuk. (Depag RI:224)

Dari ayat tersebut dapat diambil pokok pemikiran bahwa dalam memberi nasehat hendaknya dengan baik, kalau pun mereka membantahya maka bantahlah 


\section{Pendidikan Akhlak Anak dalam Keluarga Menurut Islam H. Zulkifli Agus}

dengan baik. Sehingga nasehat akan diterima dengan rela tanpa ada unsur terpaksa. Metode mendidik akhlak anak melalui nasehat sangat membantu terutama dalam penyampaian materi akhlak mulia kepada anak, sebab tidak semua anak mengetahui dan mendapatkan konsep akhlak yang benar.

\section{Metode Pembiasaan dengan Akhlak Terpuji}

Manusia dilahirkan dalam keadaan suci dan bersih, dalam keadaan seperti ini manusia akan mudah menerima kebaikan atau keburukan. Karena pada dasarnya manusia mempunyai potensi untuk menerima kebaikan atau keburukan hal ini dijelaskan Allah, sebagai berikut:

Dan jiwa serta penyempurnaannya (ciptaannya), Maka Allah mengilhamkan kepada jiwa itu (jalan) kefasikan dan ketakwaannya. Sesungguhnya beruntunglah orang yang mensucikan jiwa itu, Dan Sesungguhnya merugilah orang yang mengotorinya. (Depag RI:476-477).

Ayat tersebut mengindikasikan bahwa manusia mempunyai kesempatan sama untuk membentuk akhlaknya, apakah dengan pembiasaan yang baik atau dengan pembiasaan yang buruk. Hal ini menunjukkan bahwa metode pembiasaan dalam membentuk akhlak mujlai sangat terbuka luas, dan merupakan metode yang tepat. Pembiasaan yang dilakukan sejak dini /sejak kecil akan memebawa kegemaran dan kebiasaan tersebut menjadi semacam adat kebiasaan sehingga menjadi bagian tidak terpisahkan dari kepribadiannya. Al-Ghazali mengatakan:

Anak adalah amanah orang tuanya . hatinya yang bersih adalah permata berharga nan murni, yang kosong dari setiap tulisan dan gambar. Hati itu siap menerima setiap tulisan dan cenderung pada setiap yang ia inginkan. Oleh karena itu, jika dibiasakan mengerjakan yang baik, lalu tumbuh di atas kebaikan itu maka bahagialah ia didunia dan akhirat, orang tuanya pun mendapat pahala bersama. (Muhammad Rabbi, 2006:109)

Kutipan di atas makin memperjelas kedudukan metode pembiasaan bagi perbaiakn dan pembentuakan akhlak melalui pembiasaan, dengan demikian pembiasaan yang dilakukan sejak diniakan berdampak besar terhadap kepribadian /akhlak anak ketiak mereka telah dewasa. Sebab pembiasan yang telah dilakukan sejak kecil akan melekat kuat di ingatan dan menjadi kebiasaan yang tidak dapat dirubah dengan mudah. Dengan demikian metode pembiasaan sangat baik dalam rangka mendidik akhlak anak.

\section{Metode Keteladanan}

Muhammad bin Muhammad al-Hamd mengatakan pendidik itu besr dimata anak didiknya, apa yang dilihat dari gurunya akan ditirunya, karena murid akan meniru dan meneladani apa yang dilihat dari gurunya. Dengan memperhatikan kutipan di atas dapat dipahami bahwa keteladanan mempunyai arti pentng dalam mendidik akhlak anak, keteladanan menjad titik sentral dalam mendidik dan 
Volume 2 Nomor 1 Edisi Juni 2017

P-ISSN : 2541-3686

membina akhlak anak didik, kalau pendidik berakhlak baik ada kemungkinan anak didiknya juga berakhlak baik, karena murid meniru gurunya, senbaliknya kalauguru berakhlak buruk ada kemungkinan anak didiknya juga berakhlak buruk.

Dengan demikian keteladanan menjadi penting dalam pendidikan akhlak, keteladanan akan menjadi metode ampuh dalam membina akhlak anak. Mengenai hebatnya keteladanan Allah mengutus Rasul untuk menjadi teladan yang paling baik, Muhammad adalah teladan tertinggi sebagai panutan dalam rangka pembinaan akhlak mulia. Seperti dijelaskan dalam Al-Qur'an :

Artinya:

Sesungguhnya Telah ada pada (diri) Rasulullah itu suri teladan yang baik bagimu (yaitu) bagi orang yang mengharap (rahmat) Allah dan (kedatangan) hari kiamat dan dia banyak menyebut Allah.(Depag RI:336)

Keteladanan sempurna, adalah keteladanan Muhammad Saw menjadi acuan bagi pendidik sebagai teladan utama, dilain pihak pendidik hendaknya berusaha meneladani Muhammad Saw sebagai teladannya, sehingga diharapkan anak didik mempunyai figure yang dapat dijadikan panutan.

\section{Metode Targhib dan Tarhib}

Targhib adalah janji yang disertai bujukan dan rayuan untuk menunda kemaslahatan, kelezatan, dan kenikmatan. Sedangkan tarhib adalah ancaman, intimidasi melalui hukuman. (http//www. metode pembelajaran akhlak anak dalam keluarga, Diakses 15 Agustus 2016). Dari kutipan di atas dapat dipahami bahwa metode pendidikan akhlak dapat berupa janji/pahala/hadiah dan dapat juga berupa hukuman. Muhammad Rabbi Muhammad Jauhari menyatakan metode pemberian hadiah dan hukuman sangat efektif dalam mendidik akhlak terpuji.

Anak berakhlak baik, atau melakukan kesalehan akan mendapatkan pahala/ganjaran atau semacam hadian dari gurunya, sedangkan siswa melanggar peraturan berakhlak jelek akan mendapatkan hukuman setimpal dengan pelanggaran yang dilakukannya. Dalam al-Quran dinyatakan orang berbuat baik akan mendapatkan pahala, mendapatkan kehidupan yang baik.

Barang siapa yang mengerjakan amal saleh, baik laki-laki maupun perempuan dalam keadaan beriman, Maka Sesungguhnya akan kami berikan kepadanya kehidupan yang baik dan Sesungguhnya akan kami beri balasan kepada mereka dengan pahala yang lebih baik dari apa yang Telah mereka kerjakan. (Depag RI:222)

Berdasarkan ayat di atas dapat diambil konsep metode pendidikan yaitu metode pemberian hadiah bagi siswa berprestasi atau berakhlak mulia, dengan adanya hadiah akan memberi motivasi siswa untuk terus meningkatkan atau paling tidak mempertahankan kebaikan akhlak yang telah dimiliki. Di lain pihak, temannya yang melihat pemberian hadiah akan termotivasi untuk memperbaiki akhlaknya dengan harapan suatu saat akan mendapatkan kesempatan memperoleh hadiah. Hadiah diberikan berupa materi, doa, pujian atau yang lainnya. 


\section{Pendidikan Akhlak Anak dalam Keluarga Menurut Islam H. Zulkifli Agus}

Muhammad Jamil Zainu mengatakan,"Seorang guru yang baik, harus memuji muridnya. Jika ia melihat ada kebaikan dari metode yang ditempuhnya itu,dengan mengatakan kepadanya kata-kata "bagus", "semoga Allah memberkatimu", atau dengan ungkapan "engkau murid yang baik'. ( http//www.macam-macam metode pembelajaran akhlak anak dalam keluarga.com Diakses 15 Agustus 2016)

Sanksi dalam pendidikan mempunyai arti penting, pendidikan terlalu lunak akan membentuk anak kurang disiplin dan tidak mempunyai keteguhan hati. Sanksi tersebut dapat dilakukan dengan tahapan sebagai berikut, dengan teguran, kemudian diasingkan, dan terakhir dipukul dalam arti tidak untuk menyakiti tetapi untuk mendidik. Kemudian dalam menerapkan sanksi fisik hendaknya dihindari kalau tidak memungkinkan, hindari memukul wajah, memukul sekedarnya saja dengan tujuan mendidik, bukan balas dendam.

Dalam memberi sanksi hendaknya dengan cara bertahap, dalam arti diusahakan, dengan tahapan paling ringan, diantara tahapan ancaman dalam alQuran adalah diancam dengan tidak diridhoi oleh Allah, diancam dengan murka Allah secara nyata, diancam dengan diperangi oleh Allah dan Rasul-Nya, diancam dengan sanksi akhirat, diancam dengan sanksi dunia. Kutipan tersebut menunjukkan bahwa dalam melaksanakan hukuman dituntut berdasarkan tahapantahapan, sehingga ada rasa keadilan dan proses sesuai prosedur hukuman.

\section{Karakteristik Konsep Islam Tentang Pendidikan Anak dalam Keluarga}

Di dalam Al-Qur'an telah ada dasar-dasar pendidikan akhlak anak yang jelas mengenai pendidikan akhlak pada anak-anak yang terdapat di dalam surat Luqman antara lain:

1. Akhlak kepada Allah SWT terdapat Q..S. 31/Luqman : 13 :

Artinya:

Dan (Ingatlah) ketika Luqman Berkata kepada anaknya, di waktu ia memberi pelajaran kepadanya: "Hai anakku, janganlah kamu mempersekutukan Allah, Sesungguhnya mempersekutukan (Allah) adalah benar-benar kezaliman yang besar". (Depag RI:329)

Berdasarkan ayat tersebut di atas mengisyaratkan bagaimana seharusnya para orang tua mendidik anaknya untuk mengesakan penciptanya dan memegang prinsip tauhid dengan tidak menyekutukan Tuhannya, kemudian anak-anak hendaklah diajarkan untuk mengerjakan shalat, sehingga terbentuk manusia yang senantiasa mengingat dan kontak dengan penciptanya, seperti disebutkan dalam Q.S. 31/Luqman : 17'

Artinya:

Hai anakku, Dirikanlah shalat dan suruhlah (manusia) mengerjakan yang baik dan cegahlah (mereka) dari perbuatan yang mungkar dan Bersabarlah terhadap apa yang menimpa kamu. Sesungguhnya yang demikian itu termasuk hal-hal yang diwajibkan (oleh Allah). 
Volume 2 Nomor 1 Edisi Juni 2017

P-ISSN : 2541-3686

2. Akhlak Kepada Orang Tua

Dalam Q.S. 31/Luqman : 14

Artinya:

Dan kami perintahkan kepada manusia (berbuat baik) kepada dua orang ibu- bapanya; ibunya Telah mengandungnya dalam keadaan lemah yang bertambah- tambah, dan menyapihnya dalam dua tahun bersyukurlah kepadaku dan kepada dua orang ibu bapakmu, Hanya kepada-Kulah kembalimu.

Berdasarkan ayat di atas menjelaskan bahwasannya Islam mendidik anak-anak selalu berbuat baik terhadap orang tua sebagai rasa berterima kasih atas perhatian, kasih sayang dan semua yang telah mereka lakukan untuk anaknya. Bahkan perintah untuk bersyukur kepada Allah.

3. Akhlak Kepada Diri Sendiri

Dalam Q.S. 31/Luqman : 19 :

Dan sederhanalah kamu dalam berjalan dan lunakkanlah suaramu.

Sesungguhnya seburuk-buruk suara ialah suara keledai. (Depag RI: 329)

Berdasarkan ayat di atas dapat dipahami bahwasannya dilarang berjalan dengan congkak dan Allah SWT memerintahkan untuk sederhana dalam berjalan, dengan tidak menghempaskan tenaga dalam bergaya, tidak melenggak lenggok, tidak memanjangkan leher karena angkuh, akan tetapi berjalan dengan sederhana, langkah sopan dan tegap, memelankan suara adalah budi yang luhur. Percaya diri dan tenang karena berbicara jujur. Suara lantang dalam berbicara adalah termasuk perangai yang buruk.

4. Akhlak Kepada Orang Lain

Dalam Q.S. 31/Luqman : 18 :

Dan janganlah kamu memalingkan mukamu dari manusia (karena sombong) dan janganlah kamu berjalan di muka bumi dengan angkuh.

Sesungguhnya Allah tidak menyukai orang-orang yang sombong lagi membanggakan diri. (Depag RI: 329)

Kaitannya dengan kehidupan bermasyarakat, anak-anak haruslah dididik untuk tidak bersikap acuh terhadap sesama, sombong atas mereka dan berjalan di muka dan menghargai orang lain, karena bersikap acuh tak acuh tidak disukai oleh Allah dan dibenci manusia.

Demikianlah, Allah memberikan contoh kongkrit dalam mendidik akhlak anak-anak, di mana jika setiap orang tua dapat melaksanakan dengan baik dan benar, maka anak-anak mereka akan tumbuh menjadi manusia yang berakhlak mulia dan luhur.

Dalam konsep Islam, akhlak bagi anak ini terbagi dalam beberapa periode, diantaranya:

\section{Pendidikan Anak Prenatal (Pendidikan Anak Dalam Kandungan)}

Pendidikan anak prenatal merupakan hal yang sangat urgen diketahui, dipahami dan diamalkan oleh setiap orang tua. Dalil Islami tentang hukum wajib 


\section{Pendidikan Akhlak Anak dalam Keluarga Menurut Islam H. Zulkifli Agus}

atas orang tua untuk mendidik anak dalam kandungan adalah dalil yang sama dengan hukum wajib mendidik anak secara umum karena anak dalam kandungan adalah anak mereka yang belum lahir.

Anak adalah makhluk ciptaan Allah SWT yang hadir di tengah keluarga atas dasar fitrah. Mereka menjadi sumber kebahagiaan keluarga yang harus dijaga dan dipertahankan kesuciannya oleh kadua orang tuanya dan seluruh anggota keluarga lainnya, guna kelestarian pertumbuhan kepribadian mereka secara totalitas. Berkenaan dengan kewajiban memelihara dan mendidik tersebut terdapat dalam Q.S. 66/At-Tahrim ayat 6 :

Hai orang-orang yang beriman, peliharalah dirimu dan keluargamu dari api neraka yang bahan bakarnya adalah manusia dan batu; penjaganya malaikatmalaikat yang kasar, keras, dan tidak mendurhakai Allah terhadap apa yang diperintahkan-Nya kepada mereka dan selalu mengerjakan apa yang diperintahkan. (Depag RI: 448)

Berdasarkan ayat tersebut,Allah SWT memerintahkan kepada segenap manusia yang beriman, agar memelihara dirinya dan keluarganya dengan penuh tanggung jawab agar terhindar dari bahaya dunia dan akhirat. Terutama pada anak-anak yang membutuhkan orang tua dalam pendidikan dan masa depannya kelak.

Pendidikan anak dalam kandungan menurut Islam adalah usaha sadar dari pihak orang tua (Ayah dan ibu) untuk mendidik anak mereka yang masih dalam perut ibunya dengan cara mengikuti petunjuk Islam mengenai pendidikan, khususnya pendidikan anak dalam kandungan. (Baihaqi, 2001:12-13)

Pendidikan anak secara aktif menurut ajaran paedagogis Islami harus dimulai sejak masa diketahui bahwa anak tersebut sudah ada di dalam kandungan istri (prenatal). Dengan kata lain, pendidikan anak secara aktif sudah harus dimulai sejak masa ia di dalam kandungan dengan cara atau teknik pendidikan yang Islami.

Al-Qur'an telah menjelaskan bahwa roh (nyawa) yang ditiupkan malaikat berdasarkan izin dan perintah Allah yang lantas memberi hidup kepada anak di dalam kandungan, sudah memiliki daya kognitif tinggi. Hal ini dijelaskan Allah seperti terlihat dalam Q.S. 7/Al-A'raaf ayat 172 :

Dan (ingatlah), ketika Tuhanmu mengeluarkan keturunan anak-anak Adam dari sulbi mereka dan Allah mengambil kesaksian terhadap jiwa mereka (seraya berfirman): "Bukankah Aku Ini Tuhanmu?" mereka menjawab: "Betul (Engkau Tuhan kami), kami menjadi saksi". (Kami lakukan yang demikian itu) agar di hari kiamat kamu tidak mengatakan: "Sesungguhnya kami (Bani Adam) adalah orangorang yang lengah terhadap Ini (keesaan Tuhan)". (Depag RI: 137)

Menurut Baihaqi, A.K., bahwa syarat-syarat mendidik anak prenatal, di antaranya adalah :

a. Beriman dan bertaqwa kepada Allah merupakan syarat paling utama bagi keberhasilan upaya mendidik anak prenatal.

b. Bertekad dan berniat mendidik anak prenatal : Mendidik anak prenatal merupakan ibadah besar dalam ajaran Islam, apabila diawali dengan niat 
P-ISSN : 2541-3686

ibadah. Oleh karena itu, suami dan istri dalam upaya mendidik anak prenatal haruslah berniat dengan ikhlas karena Allah semata.

c. Menghormati orang tua dan mertua : Syarat ini merupakan syarat yang angat menentukan pula bagi keberhasilan orang tua (suami istri) mendidik anak prenatal.

d. Mendoakan anak prenatal : Mendoakan anak menjadi kewajiban orang tua sepanjang hayat, sejak anaknya masih dalam kandungan sampai lahir, dewasa dan menjadi tua pula. (Baihaqi,2001:29-50)

\section{Pendidikan Anak Sejak Lahir}

Di antara keutamaan syariat Islam bagi umatnya adalah dijelaskannya hukumhukum (pedoman) yang berhubungan dengan anak dan kaitannya dengan prinsipprinsip tentang pendidikan secara rinci sehingga pendidikan selalu mendapatkan dan kejelasan tentang masalah yang harus dijalankan terhadap bayinya yang lahir. Sebagai dasar dasar-dasar yang diundangkan Islam dan prinsip-prinsip ajaran yang dirumuskan oleh pendidik pertama, yaitu Nabi Besar Muhammad SAW, maka alangkah layaknya orang yang mendapatkan hak mendidik tersebut dapat melaksanakan kewajibannya dengan sempurna.

Sejak bayi dilahirkan, Islam telah meletakkan tata cara, sebagai ajaran dan tradisi yang baik untuk pembinaan jiwa anak-anak, di antaranya adalah: (Sodiq Ihsan,1993:124-125)

a. Bisyarah (ungkapan turut gembira)

Bagi seorang muslim, disunatkan menggembirakan dan membahagiakan saudaranya yang melahirkan anak. Hal itu dimaksudkan untuk menguatkan ikatanikatan persaudaraan dan menyebarkan sayap-sayap cinta dan kelembutan di antara keluarga muslim. Penyampaian rasa ikut gembira atas kelahiran bayi sekaligus merupakan doa yang positif di sisi Allah.

Dalam Al-Qur'an menyebutkan "kata gembira" atas kelahiran anak dengan berbagai variasi sebagai petunjuk dan pengajaran bagi umat Islam. Ucapan selamat tersebut mempunyai pengaruh besar dalam menumbuhkan ikatan-ikatan sosial dan menguatkan ikatan di antara sesama kaum muslimin.

b. Disunahkan mengadzani dan mengikamati anak yang baru lahir

Di antara hukum yang disyariatkan Islam bagi anak yang baru dilahirkan adalah mengadzani di telingan kanannya dan mengikamatinya di telinga kirinya, langsung pada saat dilahirkan. Dalam Al-Fiqh Al-Islam Wa Adillatuhu (juz 1:61) dinyatakan bahwa adzan juga disunnahkan untuk perkara selain shalat diantaranya adalah adzan di telinga anak yang baru dilahirkan seperti halnya untuk melakukan ikamah ditelinga kirinya. (http//www.nu.or.id/a.publicm.dinamics.detailids.10.id.12445.lang.ubudiyah.adzan+ untuk +bayi+yang+baru+dilahirkan.phpx diakses pada 10 Juni 2012) 


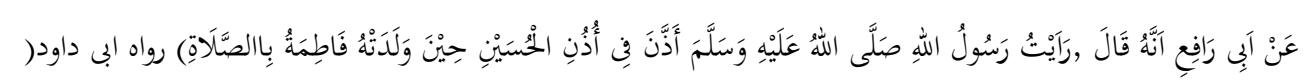

Dari Abi Rafi' bahwa dia berkata: Aku melihat Rasulullah SAW mengumandangkan adzan di telinga Husain sesaat sesudah Fatimah melahirkanny (yakni) dengan adzan shalat. (H.R. Abu Daud dan Turmudzi).

Dengan kata lain, agar ajakan kepada Allah, kepada Islam dan penyembahan kepada-Nya didahulukan dari bujukan setan, sebagaimana fitrah Allah yang menciptakan manusia sesuai dengan fitrah itu didahulukan dari pengaruh setan dan hikmat-hikmat lainnya.

c. Disunatkan mentahnik anak yang baru lahir

Di antara hukum yang disyariatkan Islam bagi anak yang baru lahir adalah disunatkan untuk men-tahnik setelah kelahirannya. Tahnik yaitu memamahkan kurma, mengulumi mulutnya dengan buah tersebut. Jika sukar mendapatkan kurma, maka bisa diganti dengan sesuatu yang manis atau cairan gula dicampur dengan air kembang, sebagai meneladani perbuatan Rasul SAW.

Hikmah dari perbuatan tersebut adalah untuk menguatkan otot-otot mulut dengan gerakan lidah karena menjilat sesuatu yang manis, sehingga anak siap untuk menetek dengan kuat dan alami. Sebaiknya orang yang mentahniknya itu orang yang bertaqwa dan saleh, sebagai tabarrok kepadanya, sebagai pengharapan agar si anak saleh dan bertaqwa pula.

d. Tasmiyah (Penamaan Anak)

Yaitu memberi nama dengan nama-nama yang baik.

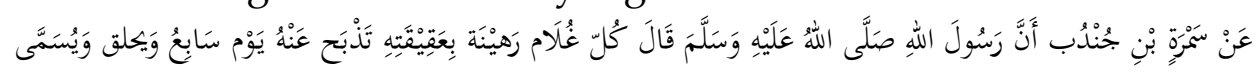

Dari Samurah, telah bersabdah Nabi SAW: "Setiap anak tergadai dengan aqiqahnya yang disembelih untuknya pada hari ketujuh, dicukur rambutnya, dan diberi nama." (HR. Ibnu Majah juz 2 hlm.1056 no. 3165)

(http//www.salampatokan.blogspot.com./2012/09/hadits.tentang.aqiqah.html. diakses pada 10 September 2016)

Hadits ini menghendaki agar anak diberi nama pada hari ke tujuh, tetapi ada juga hadits-hadits yang shahih lainnya yang menegaskan agar penamaan itu pada hari ke tujuh, boleh juga sebelum itu dan sesudahnya.

e. Aqiqah

Menurut bahasa (etimologi), العقيقة aqiqah berarti القطع yaitu memutus. Adapun menurut kamus bahasa arab kata aqiqah berarti kambing yang disembelih untuk aqiqah rambut bayi yang baru lahir. (Mahmud Yunus, 2010:274) Sedangkan menurut istilah (terminologi) syar' $i$, adalah menyembelih seekor domba untuk anak pada hari ke tujuh kelahirannya.

Aqiqah menurut pandangan hukum (fiqh) dikategorikan ke dalam sunnat muakkad, anjuran yang ditekankan. Maksudnya, meskipun Rasulullah SAW tidak 
Volume 2 Nomor 1 Edisi Juni 2017

P-ISSN : 2541-3686

menggolongkannya ke perintah yang diwajibkan, namun beliau senantiasa melaksanakannya.

\section{Pendidikan Anak Usia Dini (Anak Usia Sekolah)}

Pendidikan akhlak pada anak memang harus ditanamkan pada masa kanakkanak.agar akhlak tersebut melekat sampai anak menjadi dewasa. Di samping pendidikan akhlak yang diberikan pada masa anak prenatal (anak dalam kandungan). Pendidikan akhlak pada anak sejak lahir dan ada juga pendidikan akhlak yang diberikan pada anak usia dini (usia sekolah).

Adapun yang dimaksud dengan usia dini adalah kelompok anak yang berada dalam proses pertumbuhan dan perkembangan (koordinasi motorik halus dan kasar), intelegensi (daya pikir, daya cipta, kecerdasan emosi, dan kecerdasan spiritual), sosial emosional (sikap dan perilaku serta agama), bahasa dan komunikasi yang khusus sesuai dengan tingkat pertumbuhan dan perkembangan anak.

Berdasarkan Undang-Undang No.20 Tahun 2003, yang dimaksud dengan anak usia dini adalah kelompok manusia yang berusia 0-6 tahun. Dan berdasarkan para pakar pendidikan anak, yaitu kelompok manusia yang berusia 8-9 tahun. (Mansur, 2005:88) Setelah diketahui anak usia dini (AUD), berikut dijelaskan tentang pendidikan anak usia dini (PAUD). PAUD adalah suatu proses pembinaan tumbuh kembang anak usia lahir hingga enam tahun secara menyeluruh, yang mencakup aspek fisik dan non fisik dengan memberikan rangsangan bagi perkembangan jasmani, rohani (moral dan spiritual), motorik, akal pikir, emosional dan sosial yang tepat agar anak dapat tumbuh dan berkembang secara optimal. (Mansur, 2005:88-89)

Adapun upaya yang dilakukan mencakup stimulasi intelektual, pemeliharaan kesehatan, pemberian nutrisi dan penyediaan kesempatan yang luas untuk mengeksploitasi dan belajar secara aktif. Pendidikan anak usia dini dimulai tiga tahun sampai dengan enam tahun yang sering dikatakan sebagai pendidikan pra sekolah dan pada masa ini anak mengalami perkembangan yang sangat pesat, baik fisik, maupun psikis atau kejiwaan.

Tujuan dari pendidik anak usia dini salah satunya adalah memberikan pengalaman dan kesempatan yang akan membantu penguasaan kemampuan pada semua bidang perkembangan untuk meningkatkan kesempatan berhasil ketika anak memasuki jenjang pendidikan formal selanjutnya. Dengan demikian, jelas bahwa pendidikan anak usia dini adalah membekali dan menyiapkan anak sejak dini untuk memperoleh kesempatan dan pengalaman yang dapat membantu perkembangan kehidupan selanjutnya.

\section{Simpulan}

Berdasarkan dari hasil penelitian telah penulis uraikan mengenai Pendidikan Akhlak Anak dalam Keluarga Menurut Konsep Islam, maka dapat ditarik simpulan sebagai berikut:

Pendidikan akhlak anak dalam keluarga mempunyai peranan penting dalam meningkatkan kualitas sumber daya manusia. Secara garis besar pendidikan akhlak 


\section{Pendidikan Akhlak Anak dalam Keluarga Menurut Islam H. Zulkifli Agus}

anak dalam keluarga dapat dikelompokkan menjadi tiga, yaitu : Pembinaan Akidah dan Akhlak, Pembinaan intelektual, Pembinaan Kepribadian dan Sosial. Beberapa pegangan menuju hubungan keluarga yang sehat dan bahagia, yaitu:

1. Terciptanya kehidupan beragama dalam keluarga

2. Tersedianya waktu untuk bersama keluarga

3. Interaksi segitiga antara ayah, ibu dan anak

4. Saling menghargai dalam interaksi ayah, ibu dan anak

5. Keluarga menjadi prioritas utama dalam setiap situasi dan kondisi

Islam mempunyai metode tepat untuk membentuk anak didik berakhlak mulia sesuai dengan ajaran Islam. dengan metode tersebut memungkinkan umat Islam/ masyarakat Islam mengaplikasikannya dalam dunia pendidikan. Dengan demikian diharapkan akan mampu memberi kontribusi besar terhadap perbaikan akhlak anak.

Metode pendidikan akhlak anak dalam keluarga biasanya sering digunakan: Metode Dialog Qurani dan Nabawi, Metode kisah Qurani dan Nabawi, Metode Mauizah, Metode Pembiasaan dengan Akhlak Terpuji, Metode Keteladanan, Metode Targhib dan Tarhib.

Dalam karakteristik konsep Islam tentang pendidikan anak dalam keluarga terbagi dalam beberapa periode, diantaranya: 1) Pendidikan Anak Prenatal (Pendidikan Anak Dalam Kandungan) merupakan hal yang sangat urgen diketahui, dipahami dan diamalkan oleh setiap orang tua. Dalil Islami tentang hukum wajib atas orang tua untuk mendidik anak dalam kandungan adalah dalil yang sama dengan hukum wajib mendidik anak secara umum karena anak dalam kandungan adalah anak mereka yang belum lahir. 2) Pendidikan Anak Sejak Lahir, sejak bayi dilahirkan Islam telah meletakkan tata cara mendidik anak sejak ia dilahirkan, seperti mengumandangkan adzan dan iqamah di telinga kanan dan kirinya sebagai ajaran dan tradisi yang baik untuk pembinaan jiwa anak-anak. 3) Pendidikan Anak Usia Dini (Anak Usia Sekolah) yaitu pendidikan akhlak pada anak memang harus ditanamkan pada masa kanak-kanak agar akhlak tersebut melekat sampai anak menjadi dewasa. 
RAUDHAH Proud To Be Professionals gurnal Tarbiyakndlamiyak

Volume 2 Nomor 1 Edisi Juni 2017

P-ISSN : 2541-3686

\section{DAFTAR PUSTAKA}

Al-Qur'an dan Terjemahnya. Departemen Agama RI. Bandung: CV Penerbit Diponegoro. 2006

An-Nahlawi, Abdurrahman. Pendidikan Islam Di Rumah, Sekolah dan Masyarakat. Terj. Shihabuddin. Jakarta: Gema Insani. 1995.

A.K., Baihaqi. Mendidik Anak dalam Kandungan Menurut Ajaran Paedagogis Islami. Jakarta: Darul Ulum Press. 2001.

Bukhari. Shahih Bukhari kitab al-janaiz bab Ma Qila fi Aulad al-Musyrikin. ( juz 5 no.1296)

Shahih Bukhari, Juz 4. Beirut: Dar Al Fikr. 1981.

Dahlan, Aisyah. Membina Rumah Tangga Bahagia dan Peranan Agama dalam Rumah Tangga. Jakarta: Jaamun 1969.

Daradjat, Zakiah, dkk. Ilmu Pendidikan Islam. Jakarta: PT Bumi Aksara. 2011.

. Pendidikan Islam Dalam Keluarga dan Sekolah. Jakarta: CV. Ruhama. 1995.

D. Gunarsa, Singgih. Psikologi Untuk Keluarga. Jakarta: BPK Gunung Mulia. 1984.

http//m.salamdakwah.com/baca-artikel/urgensi-akhlak-dalam-membangunmasyarak-at.html diakses pada 10 September 2012.

http//al-poenya.blogspot.com/2011/11/resume-buku-akhlak-tasawuf-12.html. diakses pada 10 September 2016

http//senyumkudakwahku.blogspot.com./2012/06/makalah-akhlak.html. diakses pada10 September 2016

http://www.kampusislam.com/index.php?pilih =news\&mod=yes\&aksi. Diakses pada 01 Aguats 2016

http//www.macam-macam metode pembelajaran akhlak anak dalam keluarga. Diakses 15 Agustus 2016

http//www.metode pembelajaran akhlak anak dalam keluarga. Diakses 15 Agustus 2016

http//www.nu.or.id/a.public-m.dinamic-s.detail-ids.10.id.12445.lang.ubudiyah.adzan

+ untuk+bayi+yang+baru+dilahirkan.phpx diakses pada 10 Agustus 2016

http//www.salampatokan.blogspot.com./2012/09/hadits.tentang.aqiqah.html. diakses pada 10 September 2016

http//zairifblog.blogspot.com/2010/11/akhlak-tasawuf.html?m=1 


\section{Pendidikan Akhlak Anak dalam Keluarga Menurut Islam \\ H. Zulkifli Agus}

Hubermen, A. Michael, Miles. Analisis data kualitatif. Terj Tjetjep Rohedi. Jakarta: UI Press. 1992.

Ihsan, Shodiq. Keluarga Muslim Dalam Masyarakat Modern. Bandung: PT. Remaja Rosdakarya. 1993.

Jalaluddin. Mempersiapkan Anak Shaleh (Telaah Pendidikan Terhadap Sunnah Rasul Allah SWT.). Jakarta: PT. Raja Grafindo Persada. 2000.

J. Goode, William. Sosiologi Keluarga. Jakarta: Bumi Aksara. 1995.

Mansur. Pendidikan Anak Usia Dini Dalam Islam Yogyakarta: Pustaka Pelajar. 2005.

Muhaimin. Pemikiran Pendidikan Islam: Kajian Filosofis dan Kerangka Dasar Operasionalnya. Bandung: Trigenda Karya. 1993.

M. Resyahri, Muhammad. Anak di Mata Nabi. Jakarta: Al-Huda. 2009.

Rahmat, Jalaluddin dan Muhtar Gandatama. Keluarga Muslim Dalam Masyarakat Modern. Bandung: Remaja Rosdakarya. 1994.

Sujana, Djuju. Peranan Keluarga Dalam Lingkungan Masyarakat. Bandung: Remaja Rosdakarya. 1996.

Suwarno. Pengatur Umum Pendidikan. Jakarta: Aksara Baru. 1985.

----------. Pengantar Umum Pendidikan. Jakarta: Rineka Cipta. 1992.

Tafsir, Ahmad. Pendidikan Agama Dalam Keluarga. Bandung: Remaja Rosdakarya. 1996.

Tauhis MS., Abu. Beberapa Aspek Pendidikan Islam. Yogyakarta: 1990.

Yunus, Mahmud. Kamus Arab Indonesia. Jakarta: PT. Mahmud Yunus wa Dzurriyah. 2010 